\title{
Participatory Video on Menstrual Hygiene: A Skills-Based Health Education Approach for Adolescents in Nepal
}

This article was published in the following Dove Press journal:

Adolescent Health, Medicine and Therapeutics

\author{
Sudha Ghimire (1D \\ Bhimsen Devkota (iD) ${ }^{2}$ \\ 'Graduate School of Education, \\ Department of Health Education, \\ Tribhuvan University, Kirtipur, Nepal; \\ ${ }^{2}$ Mahendra Ratna Campus, Department \\ of Health Education, Tribhuvan \\ University, Tahachal, Nepal
}

\begin{abstract}
School adolescents who are in the formative years of their lives are in stark need of appropriate and innovative skills-based health education and information. In this paper, we aim to explain how the participatory video (PV) approach was used in exploring the issues concerning adolescent reproductive health, particularly on menstrual hygiene among school adolescents in Chitwan district of Nepal. The students were engaged in the PV process for more than 6 months. They were given smart android phones with a 15-megapixel camera to shoot the video. The school adolescents regarded PV as an innovative and participatory medium for developing their critical thinking skills, collaborative skills, communication skills, and creative skills, which are required in the twenty-first century.
\end{abstract}

Keywords: adolescents, participatory video, menstruation, school

\section{Introduction}

In Nepal, there are approximately six million adolescents or $24 \%$ of the total population. This age group has the potential in shaping the future of the country. Despite numerous efforts made by the government and developmental agencies for achieving the Sustainable Development Goal by 2030. However, critical gaps remain in addressing the needs of the adolescents in Nepal. ${ }^{1}$ These gaps can be observed in many forms including access to, and utilization of, the correct reproductive health information and skills. School adolescents who are in the formative years of their lives need to be equipped with appropriate skills-based health education. In this context, we adopted a need-based, adolescent-friendly, participatory and innovative process using a context responsive approach for assessing the needs of the adolescents in developing a skill-based health education and equipping them for addressing their future needs. This paper explains how the participatory video making was used in exploring the issues concerning adolescent reproductive health, particularly on menstrual hygiene among adolescents in a community school of Nepal.

Partnership for 21st Century Learning, or P21, has identified learning and innovation skills, digital literacy skills, and career and life skills as essential skills for students. ${ }^{2}$ Similarly, 21st Century Learning details four learning objectives (4C) including critical thinking, creativity, communication, and collaboration. ${ }^{3}$ Furthermore, the WHO (2006) has highlighted a skills-based health education as an approach to creating and maintaining healthy conditions and lifestyles by using
Correspondence: Sudha Ghimire

Graduate School of Education,

Department of Health Education,

Kantipur 44618, Nepal

Tel +977 984I458534

Email sudha.ghimire42@gmail.com
Adolescent Health, Medicine and Therapeutics 2020:I I II9-122 
a variety of learning experiences, emphasizing participatory methods, to increase knowledge and develop attitudes and skills. ${ }^{4}$

The study by Lachter et al claimed that PV approach is successful in reaching out to the adolescents. ${ }^{5}$ In this context, as a part of the Participatory Action Research (PAR) approach, the study found that the Participatory video (PV) was an effective means to involve adolescents in exploring their understanding of menstruation, the challenges they face during menstruation and giving them voices. Participatory video is simply a film-making process where participants themselves decide what to capture, where to film, and to whom to show the video. It should be noted that they are not professional video makers. ${ }^{6}$ The research findings reveal that the PV process was instrumental in developing the $4 \mathrm{C}$ skills, namely, critical thinking, communication, collaboration, and creative thinking among the school adolescents.

\section{Methodology}

This study adopted the PAR approach in a community school setting located in the central plain of Nepal bordering to India. The school is funded by the government, while the action research project was funded by Norwegian Agency for Development Cooperation (Norad) and jointly implemented by the consortium of Tribhuvan University, Kathmandu University, and Norwegian University of Life Sciences. Through the census sampling all together 166 students (Male: 77, female: 89 ) ages 10 to 14 participated in the video-making process. The girls were in the average age of menarche. The students volunteered to split in small groups of 10-12 students for shooting the video. They were given smart android phones with a 15-megapixel camera to shoot the video. The students were engaged in the PV process for more than six months. Their responses in the focused group discussion and contents of the PV were translated into English language. The transcripts were analyzed on different themes. Through this PV four innovative and team work skills were developed. They include; critical thinking, communication skills, collaboration skills and creative thinking. Ethical approval of the research was provided by Nepal Health Research Council (approval number 733/2018), and this study was conducted in accordance with the Declaration of Helsinki. Informed written consent was taken from the school administration and students prior to study and verbal consent was obtained from the parents. A separate written consent was taken from parents for publishing the picture (Figure 1). In the

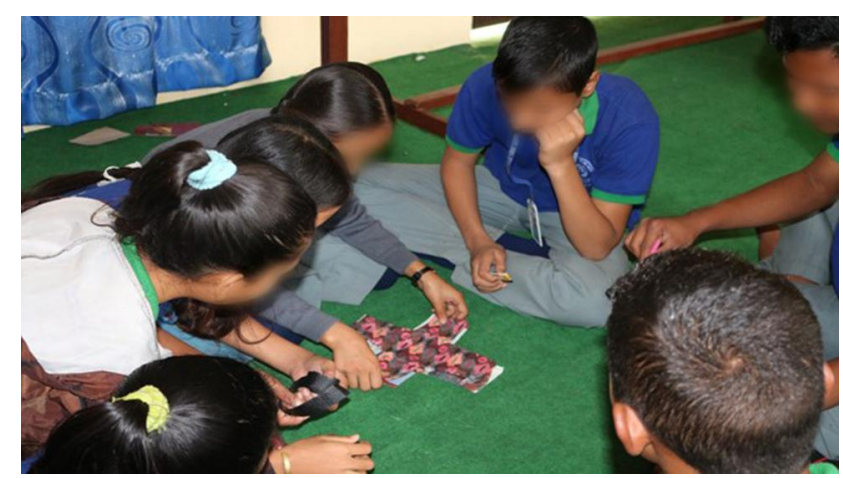

Figure I Students collaborating to make a re-usable sanitary pad.

first phase, students developed a four-minute-long video on menstruation interviewing their classmates focusing on the problems they had long been facing and their expectation from the school management. In the second phase, a seven-minute video was produced about the process of making re-usable homemade sanitary cloth pads. This was made after students' participation in 7 days' training for making sanitary pads.

\section{Result and Discussion}

The participatory video making by the school adolescents involved four innovative and team work processes, involving critical thinking, communication skills, collaboration skills, and creative thinking.

\section{Critical Thinking for PV Making Process}

Critical thinking involves accessing, analyzing, and synthesizing information that can be used for problem solving. ${ }^{3}$ Initially, the students explored issues related to menstruation through the participatory action research (PAR) process. Adolescents were given the opportunity to explore their day-to-day problems and potential solutions. To do this, they were exposed to comprehensive reading, cross word puzzles, newspaper articles, and short stories related to menstruation. Furthermore, the authors shared their assessment findings, which was collected during baseline study for the project, which showed that $12 \%$ of adolescent girls at the school did not wash their genitals after changing pads, and more than one quarter of the girls used unclean clothes or rags to absorb the blood. They brainstormed and discussed their problems. After the discussion, they came up with some solutions in managing menstruation which are listed in Table 1. 
Table I List of Problems and Probable Solution Given by the Students for Managing Menstruation

\begin{tabular}{|l|l|}
\hline Problems & $\begin{array}{l}\text { Probable Solution from } \\
\text { Students' View }\end{array}$ \\
\hline Lack of access to sanitary pads & $\begin{array}{l}\text { Request access to pads from } \\
\text { school administration }\end{array}$ \\
\hline $\begin{array}{l}\text { Commercial sanitary pads are } \\
\text { expensive }\end{array}$ & $\begin{array}{l}\text { Search for alternatives to } \\
\text { commercial pads }\end{array}$ \\
\hline $\begin{array}{l}\text { Lack of soap, water, dustbin to } \\
\text { dispose of pads in school toilets }\end{array}$ & $\begin{array}{l}\text { Request soap from school } \\
\text { administration and mobilize child } \\
\text { club to empty the dustbin }\end{array}$ \\
\hline $\begin{array}{l}\text { Boys tease when they know } \\
\text { about girls' menstruation }\end{array}$ & $\begin{array}{l}\text { Make boys aware that } \\
\text { menstruation is a monthly cycle in } \\
\text { females }\end{array}$ \\
\hline $\begin{array}{l}\text { Issues of leakage and resulting } \\
\text { embarrassment }\end{array}$ & Change pads frequently \\
\hline $\begin{array}{l}\text { No supply of medicine or hot } \\
\text { water for pain during periods }\end{array}$ & $\begin{array}{l}\text { Request from school } \\
\text { administration }\end{array}$ \\
\hline $\begin{array}{l}\text { Feels difficult to share their } \\
\text { problems related to } \\
\text { menstruation }\end{array}$ & $\begin{array}{l}\text { Provide a female teacher as } \\
\text { a focal contact person }\end{array}$ \\
\hline $\begin{array}{l}\text { Feel inferior when they have } \\
\text { restrictions at home during } \\
\text { menstruation }\end{array}$ & Educate parents \\
\hline
\end{tabular}

After discussions, the students identified the issues they could share with the teachers, parents, and school administration relating to their menstruation problems. Finally, they came up with an idea of making a participatory video on menstruation to raise their voices.

It would be a good idea, if we could say our problems and capture it on video ... like a famous journalist name of journalist) does and shows on television. We can make a similar video and share it with the school administration and parents too. (14 year girl)

Thus, the students initiated a chain of critical thinking, particularly making use of modern technology to share their problems.

\section{Communication Skills in PV}

Communication skill is not only limited to passing information or feelings to another, it is a meaningful conversation as well. ${ }^{3}$ When students were engaged in making the PV, they developed communication skills. For the first time, the girl students spoke freely with the boy students about menstruation.
Earlier, it was difficult for me to talk about menstruation because boys think they can tease me when I talk about it. But when we decided to make the video, we had to talk with them, and slowly we felt more confident talking about menstruation with the boys. It is a new experience asking your friends and capturing that on a video. (13-year old girl student)

Adding to her comments, a boy who was also involved in PV shared:

I used to think that menstruation was a girl's issue ....it was their problem ... but when I listen to girls in the class talk about the problems they were facing, I realized that we need to help them. While giving an interview for the video, initially I was nervous ... but slowly when I started talking, it became comfortable. Now I have developed confidence to talk with anyone, anywhere. (14 years old boy student)

After screening the final video, the students conducted a half-day workshop involving stakeholders: teachers, member of the School Management Committee (SMC), parents, and local leaders, all were participated voluntary. There were all together 30 participants in workshop, i.e 10 teachers, 8 SMC, 10 Parents, 2 local leaders. Stakeholders were divided into three groups and given three themes: feeling about the video; how MHM issues could be solved?; their roles in the proper management of menstrual hygiene. After watching the video, they agreed that in upcoming days they would keep MHM related issues in first priority. Thus, the students developed communication skills to raise their voices.

\section{Collaboration Skills}

The students learned to work collaboratively in groups while developing the PV. Collaboration means working together for a common goal. ${ }^{3}$ In Nepal, most of the teachers use the deductive teaching method, relying on textbooks to deliver the knowledge and skills relating to reproductive health. ${ }^{7}$ Instead, we initiated collaborative learning through $\mathrm{PV}$, giving adolescents an opportunity to work cooperatively (refer Figure 1). They collaborated in completing multiple tasks - selecting the venue for shooting, choosing the themes they planned to discuss, keeping and discarding footages, selecting the interviewer and interviewee, and which questions should be asked of the boys and which of the girls. They collaborated not only with their peers but also with the teachers and school administrators in conducting the workshops. 
Before involvement with this PV process, we used to discuss with friends about the assignment given to us and how we would feel about a particular subject. Sometimes we used to play with friends for extracurricular activities. This is the first time that we have worked closely in a group regardless of being senior or junior students. We learned how to develop a common understanding with others for achieving a common goal. (14 years old boy student)

\section{Creative Thinking Skills}

In this study creative thinking was considered to be the best solution for management of the problems that students were facing. When students shared that they were facing challenges in the hygienic management of menstruation, but had not yet shared their problems with the school administration, they reported it was awkward to talk about it as it was considered a taboo. They came up with the idea of creating a participatory video examining the existing menstrual hygiene problems. They concluded that the PV could serve as a medium for raising their concerns with the teachers and the parents. This was the start of creative thinking amongst the students. After watching the video, the school administration realized that the girls were facing problems during their menstruation period. They were committed to resolving them. Furthermore, they found that some of the students were using commercial pads for an extended time (more than 12 hours) to save money, and some girls used clothes or rags to absorb the blood. When they learned how to make an improvised re-usable pad, they developed the idea for another video in which they could explain the procedure and then use the video in educating other students and parents. This was how they developed their creative skills.

\section{Conclusion}

The school adolescents regarded PV as an innovative medium for developing the critical thinking skills, collaborative skills, communication skills, and creative skills that are required in the twenty-first century. Moreover, they considered PV as one approach for acquiring skillsbased health education, and linking their real problems to creative solutions. Skills are interrelated, and one activity might be helpful for developing many skills.

\section{Acknowledgments}

The authors acknowledge the NORHED Rupantaran Project for providing funding to this study. We acknowledge the students and Ms. Jennifer Weidmann for copy editing the article.

\section{Disclosure}

The authors report no conflicts of interest in this work.

\section{References}

1. UNICEF. Access to communication media and the acceptance of violence among adolescent females in Nepal: nepal Multiple Indicator Cluster Survey (MICS). 2014 further analysis report. 2018. Available from: https://www.unicef.org/nepal/media/1511/file/ AccesstoCommunicationMediaandtheAcceptanceofViolenceAmongA dolescentsFemaleinNepal.pdf. Accessed September 4, 2020.

2. Connolly M. Skills-Based Health Education. 2nded. USA: Jones \& Barltett learning Boooks; 2020. Available from: https://books.google. com.np/books?id=vVldjwEACAAJ\&printsec $=$ frontcover\&source $=$ gbs_ge_summary_r $\&$ cad $=0 \# \mathrm{v}=$ onepage $\& \mathrm{q} \& \mathrm{f}=$ false. Accessed September 4, 2020 .

3. Sipayung HD, Sani RA, Bunawan W. Collaborative inquiry for $4 \mathrm{C}$ skills. Adv Soc Sci Educ Humanit Res. 2018;200:440-445.

4. Clarke D, Maier C, Birdthistle I, Buckland P. Skills for Health: Information Series on School Health, Document 9. USA: WHO;2006. Available from: https://www.skillsplatform.org/organisa tion/skills-for-health/courses/e-learning. Accessed September 4, 2020.

5. Bernstein R, Mph L, Komro KA, Mph SV, Perry CL, Williams CL. High school students ' Efforts to reduce alcohol use in their communities: project Northlands youth development component. J Heal Educ. 1999;30(6):330-342. doi:10.1080/10556699.1999.10604653

6. Lunch C. Insights into Participatory Video. First. UK: InsightShare; 2006.

7. Acharya DR, Van Teijlingen ER, Simkhada P. Opportunities and challenges in school-based sex and sexual health education in Nepal. Kathmandu Univ Med J. 2009;7(28):445-453. doi:10.3126/kumj. v7i4.2773

\section{Publish your work in this journal}

Adolescent Health, Medicine and Therapeutics is an international, peer-reviewed, open access journal focusing on health, pathology, and treatment issues specific to the adolescent age group. All aspects of health maintenance, preventative measures and disease treatment interventions are addressed within the journal and practitioners from all disciplines are invited to submit their work as well as healthcare researchers and patient support groups. The manuscript management system is completely online and includes a very quick and fair peerreview system. Visit http://www.dovepress.com/testimonials.php to read real quotes from published authors. 